\title{
20
}

\section{Calibration of BASINS HSP-F in Support of a Watershed Approach to CSO Long Term Control Planning}

\author{
M.F. Perrelli, K.N. Irvine and T.S. Lee
}

BASINS (Better Assessment Science Integrating point and Nonpoint Sources) HSP-F was used as part of the watershed approach in developing the City of Buffalo Long Term Control Plan for CSO abatement. More specifically, the focus of this chapter is the Buffalo River watershed and $33 \mathrm{CSOs}$ that discharge to the lower Buffalo River. Estimated sediment, bacteria, and metals loads from the watershed and CSOs were compared for design storms of different frequencies and on an annual basis. Loadings of these contaminants from the upper watershed exceeded the CSO loadings. It was essential to have a calibrated BASINS HSP-F model to make the watershed loading estimates. This chapter reviews the procedure and results of the model calibration effort, including some of the challenges to estimating both runoff quantity and sediment transport.

The Buffalo River watershed is 446 square miles $\left(1,155 \mathrm{~km}^{2}\right)$ in area and has a USGS gauge station on each of the three major tributaries, Cazenovia Creek, Cayuga Creek, and Buffalo Creek. The BASINS HSP-F, version 2, was calibrated on an annual basis, using daily mean flow for a dry year (1995), a wet year (1992), and an "average" year (1990). The $r^{2}$ between observed and modeled daily mean flow for the three gauge sites (0.56-0.73) and the Nash Sutcliffe coefficient (0.06-0.50) tended to be better for the "average" year. The model was most sensitive to changes in the parameters

Perrelli, M., K. Irvine and T.S. Lee. 2005. "Calibration of BASINS HSP-F in Support of a Watershed Approach to CSO Long Term Control Planning." Journal of Water Management Modeling R223-20. doi:

10.14796/JWMM.R223-20.

(C) CHI 2005 www.chijournal.org ISSN: 2292-6062 (Formerly in Effective Modeling of Urban Water Systems. ISBN: 0-9736716-0-2) 
UZSN and LZSN (upper and lower zone nominal soil moisture storage, respectively).

Larger errors in model estimates for the years 1990, 1992, and 1995 frequently were traced to the rainfall data used to drive the runoff simulations. The rainfall record used in the calibration was for only one gauge site, the Buffalo Airport. Observation of weather radar and qualitative notation from field personnel indicated that considerable spatial variability occurred in rainfall patterns for the area. Validation runs were conducted for the year 2000 using only the Buffalo Airport rainfall data and spatially averaged rainfall data that also included two other rain gauges within the watershed. The validation run with the spatially averaged rainfall data had a higher $r^{2}$ and Nash Sutcliffe coefficient as compared to the validation run with the Buffalo Airport data alone.

A lengthy time series of observed suspended solids data was not available to calibrate the sediment erosion and transport component of the model. However, turbidity data measured continuously at various sites along the Buffalo River in 2000 were available and relationships between suspended solids and turbidity were developed using least squares regression. For the purpose of model calibration the daily mean turbidity values were run through the appropriate regression equation to construct a suspended solids time series. Results of the calibration run for an example river reach that represents Cazenovia Creek, near the city line, and for the lower Buffalo River, near the Ohio St. bridge were evaluated in detail. Visually, the observed and modeled sediment time series for the two reaches corresponded, although quantitatively, the $r^{2}$ was low (in the range of 0.29). The model did a better job of representing erosion and transportation from the upper part of the watershed and had greater difficulty in representing the sediment deposition processes within the more hydraulically complex dredged channel (Ohio St. bridge site).

\subsection{Introduction}

Under the U.S. EPA's National Combined Sewer Overflow (CSO) Control Policy (1994), agencies responsible for the operation of combined sewer systems must develop a Long Term Control Plan (LTCP) for CSO abatement. An LTCP must characterize the quantity and quality of flow in the combined sewer system as well as evaluate receiving water impacts. In general, the U.S. EPA has actively promoted a watershed approach to water quality analysis 
and management (U.S. EPA, 2001a) and more specifically recommended that LTCP development should consider watershed-wide issues:

"EPA recognizes that urban water quality may be affected by a combination of CSOs, storm water discharges, other point sources and nonpoint source runoff. These sources may be most effectively addressed on a watershed basis or through TMDL analyses. The CSO Policy encourages permitting authorities to evaluate water pollution control needs on a watershed management basis and coordinate CSO control efforts with other point and nonpoint source control activities." (U.S. EPA, 2001b)

Furthermore, the U.S. EPA (1999) encouraged the use of models to explore the dynamics of pollutant loads under baseline and competing CSO abatement scenarios to help assess the receiving water benefits of the different abatement scenarios. The U.S. EPA (1999) guidance noted that a variety of models and modeling approaches were available and selection of an appropriate modeling methodology was site and project-specific.

The BASINS system was developed under the auspice of the U.S. EPA primarily to address three objectives: (i) facilitate examination of environmental information; (ii) provide an integrated watershed and modeling framework; (iii) support analysis of point and nonpoint source management alternatives. Increasingly, BASINS is being used to evaluate dynamics of indicator bacteria levels and assist with the development of total maximum daily loads (TMDLs) for watersheds in the U.S. (Whittemore and Beebe, 2000; U.S. EPA, 2001c; Virginia Department of Environmental Quality, 2002a,b; Irvine et al., 2003a). Because the Buffalo River is a Great Lakes Area of Concern, with attendant use impairments that potentially could be generated within the entire watershed, it was decided that BASINS would provide the flexibility to support the requirements of the current LTCP development, as well as future studies, such as TMDL assessment. The HSP$\mathrm{F}$ model is part of the BASINS system and was used for this project. Estimated sediment, bacteria, and metals $(\mathrm{Pb}, \mathrm{Zn}, \mathrm{Hg}, \mathrm{Cu})$ loads from the Buffalo River watershed and the 33 CSOs in the lower Buffalo River were compared for design storms of different frequencies and on an annual basis. Loadings of these contaminants from the upper watershed exceeded the CSO loadings and the results of these loading evaluations are reported in detail elsewhere (Irvine et al., 2003b). It was essential to have a calibrated BASINS HSP-F model to make the watershed loading estimates. This chapter reviews the procedure and results of the model calibration effort, including some of the challenges to estimating both runoff quantity and sediment transport. 


\subsection{The Buffalo River Watershed}

The Buffalo River watershed has a total drainage area of 446 square miles $\left(1,155 \mathrm{~km}^{2}\right)$ and is fed by three major tributaries: Cayuga Creek, Buffalo Creek, and Cazenovia Creek (Figure 20.1). The Buffalo River itself begins at the confluence of Cayuga and Buffalo creeks, approximately 8.1 miles (13 $\mathrm{km})$ above the mouth at Lake Erie. Cazenovia Creek enters the Buffalo River about 6 miles $(9.6 \mathrm{~km})$ above the mouth.
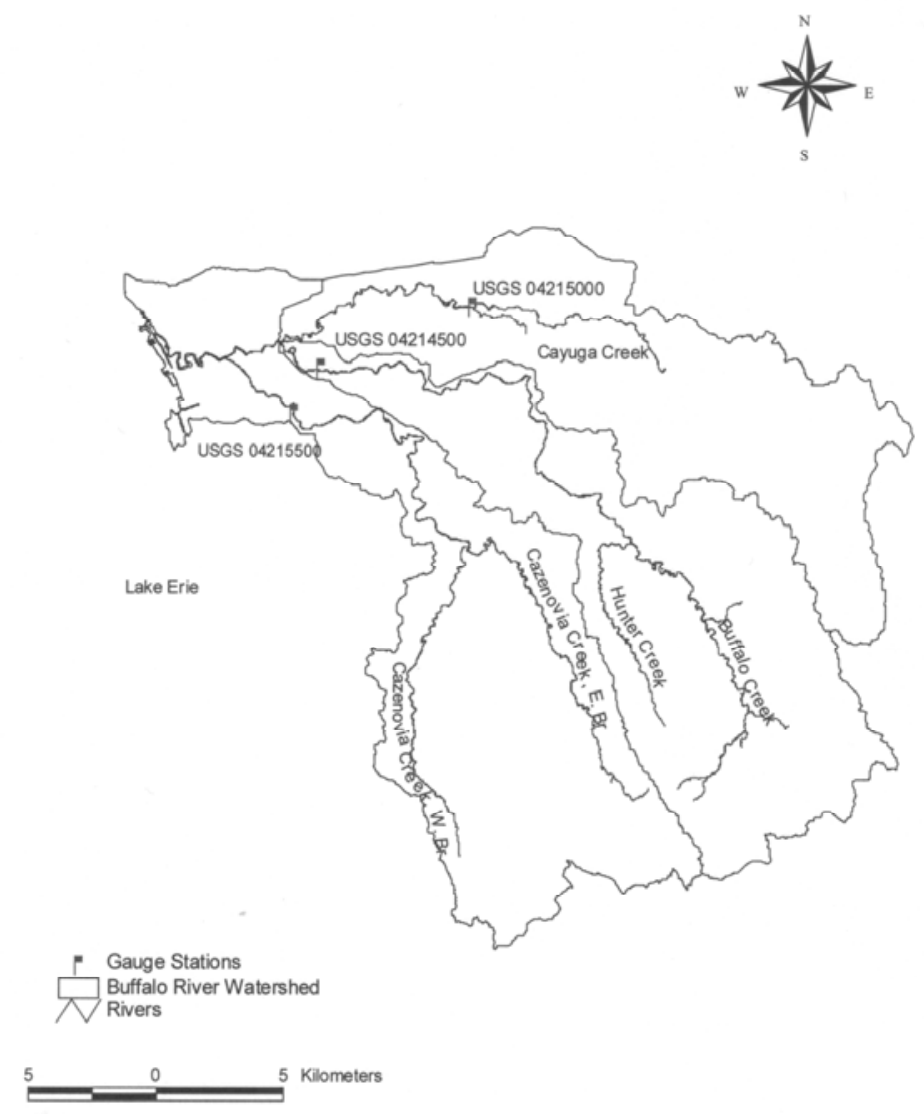

Figure 20.1 Buffalo River watershed showing the locations of the USGS gauge stations used for model calibration and validation. 
Land use within the watershed varies and was mapped out as part of the GIS data. In general, much of the upper portion of the watershed is characterized by woods and farmland, but prior to joining the Buffalo River the creeks also pass through several small communities and receive industrial, commercial, institutional, residential, and municipal discharges.

Most of the watershed lies within Erie County, and two physiographic regions. The northern half and western edge of the county are within the ErieOntario Lake Plain Province, while the southern half of the county is within the Allegheny Plateau Province. The Erie-Ontario Province formerly was a glacial lakebed and therefore has limited relief except in the area of major drainage ways. The southern and eastern boundaries of the Erie-Ontario Province are formed primarily by glacial lake beaches. The Allegheny Plateau has characteristic wide ridge tops and flat-topped hills. Sargent (1975) indicated that the tributaries flowing through the Allegheny Plateau primarily are bedrock streams with numerous rapids and small waterfalls. The slopes of these streams generally range between 0.001 and 0.007 .

Erie County experienced several glacial advances and retreats between approximately 300,000 and 10,000 B.P. and the resulting mix of deposited material has given rise to several soil types. Various tills are an important parent material in the county, although soils also have developed from glacial lacustrine and glacial outwash deposits. Modern alluvial deposits along major waterways have produced grayish brown silt loams that exhibit drainage classifications from well to poorly drained. Nearly $70 \%$ of the soils within Erie County are some type of silt loam. Approximately $8 \%$ of the soils in the county have been classified as "urban soils" (U.S. Department of Agriculture (USDA), 1986).

Annual total precipitation at the Buffalo Airport averages 38.6 inches $(98 \mathrm{~cm})$, with February being the driest month $(2.3$ inches $(5.9 \mathrm{~cm})$ of precipitation) and August being the wettest month $(4.2$ inches $(10.6 \mathrm{~cm})$ of precipitation). The lowest monthly mean flow recorded at USGS gauge stations on each of the tributaries (Figure 20.1) typically occurs in July and August when evapotranspiration is highest (Cayuga Creek $-24.6 \mathrm{cfs}\left(0.70 \mathrm{~m}^{3}\right.$ $\left.\mathrm{s}^{-1}\right)$; Buffalo Creek $-45.8 \mathrm{cfs}\left(1.30 \mathrm{~m}^{3} \mathrm{~s}^{-1}\right)$; and Cazenovia Creek - $47.8 \mathrm{cfs}$ $\left.\left(1.35 \mathrm{~m}^{3} \mathrm{~s}^{-1}\right)\right)$. Highest monthly mean flow on the three tributaries typically occurs in March (Cayuga Creek - $342 \mathrm{cfs}\left(9.68 \mathrm{~m}^{3} \mathrm{~s}^{-1}\right)$; Buffalo Creek - 495 $\operatorname{cfs}\left(14.0 \mathrm{~m}^{3} \mathrm{~s}^{-1}\right)$; and Cazenovia Creek $\left.-551 \mathrm{cfs}\left(15.6 \mathrm{~m}^{3} \mathrm{~s}^{-1}\right)\right)$ as the result of snowmelt and spring rainfall.

The Buffalo River Area of Concern (AOC) spatially extends from the mouth of the Buffalo River to the point upstream at which backwater effects during Lake Erie's highest monthly average level does not impact river flow. 
Historically, the AOC was heavily industrialized, with activities including: steel production; coking operations; oil refining; chemical and dye production; and flour milling (Sauer, 1979; Irvine et al., 2003c). Industrial activity has declined along the river in the last decade and steel production, coking operations, and oil refining has ceased.

Much of the Buffalo River AOC is designated as a navigable channel and is maintained at a minimum depth of approximately $22 \mathrm{ft}(7 \mathrm{~m})$ by the Buffalo District Army Corps of Engineers. This dredged reach is wider and deeper than the tributaries, but the bed slope is shallower, averaging 0.0002 (Sargent, 1975). As a result of the changes in hydraulic geometry, flow velocities within the AOC typically are less than those of the tributaries, producing local shoaling areas as sediment deposits. The Buffalo River Improvement Corporation (BRIC) was created in 1967 to supply industries along the Buffalo River with water for cooling and processing purposes. The water is pumped from Lake Erie and ultimately augments flows in the Buffalo River. The design operation of the BRIC system is $77 \mathrm{cfs}\left(2.18 \mathrm{~m}^{3} \mathrm{~s}^{-1}\right)$ and during its early years of operation often contributed $90 \%$ of the total river flow through the drier summer months (Sauer, 1979). As industry declined along the river, so too has the BRIC pumping rate. Recent pumping rates averaged between 8 and $23 \mathrm{cfs}\left(0.23-0.66 \mathrm{~m}^{3} \mathrm{~s}^{-1}\right)$.

Historical (1940-1985) monthly mean inflows into the upper end of the AOC range between approximately $1,589 \mathrm{cfs}\left(45 \mathrm{~m}^{3} \mathrm{~s}^{-1}\right)$ in March and $117 \mathrm{cfs}$ $\left(3.3 \mathrm{~m}^{3} \mathrm{~s}^{-1}\right)$ in July (Meredith and Rumer, 1987). The AOC can exhibit estuarine-like characteristics due to wind set-up, when water levels at the eastern end of Lake Erie can rise up to $8 \mathrm{ft}(2.4 \mathrm{~m})$ over the course of several hours. This wind set-up principally is associated with higher velocity, southwesterly winds blowing parallel to the longitudinal axis of the lake (Irvine and Eberhardt, 1992). These wind set-up conditions can produce flow reversals for several kilometers up the river. Thermal stratification between lake and river water also has been observed for several kilometers upstream, primarily during wind set-up (Irvine et al., 1992).

\subsection{Data for the Modeling Effort}

\subsubsection{Data Supplied by the BASINS System}

Data layers to perform a watershed analysis are included with the BASINS system. The BASINS model and related databases are available for download 
from the U.S. EPA web site (www.epa.gov/ost/BASINS). There are essentially three sets of data in BASINS: (i) spatial data; (ii) environmental monitoring data; and (iii) point source data. The spatial data consist of four types: (i) watershed boundary and associated data such as land use, soils, gauge stations; (ii) DEM- digital elevation model; (iii) Reach File Version 1 and 3 (stream networks, general and detailed); and (iv) meteorologic data. The spatial data available in BASINS are provided by various government agencies. Land use and watershed boundary data are supplied by the USGS. Soil coverages are based on STATSGO (State Soil Geographic Database) soil data from the U.S. Department of Agriculture, Natural Resources Conservation Service. Weather data are supplied by the National Oceanic and Atmospheric Administration (NOAA). Digital formats of the stream networks (RF1 and RF3) and elevation data are supplied by the U.S. EPA. Assessment of a watershed requires knowledge of the topography and land use characteristics in the watershed. To facilitate this, the BASINS system is equipped with a Watershed Characterization Report Tool that produces summary statistics for selected spatial coverages.

Land use data included in BASINS were compiled from satellite data collected by the USGS from the mid-1970s through the early 1980s. The land use maps were classified using Level 1 and Level 2 of the Anderson Classification system. This classification system was designed in the late 1970s by the USGS for use with remotely sensed data (Anderson et al., 1976). Level 1 of the classification system includes nine broad land use categories such as "Urban or Built up" and "Agricultural Land". Level 2 includes detailed land use types under the Level 1 classification such as "Residential" and "Cropland and Pasture". Clearly, for areas that have experienced rapid urbanization since the early 1980's the BASINS data are dated and less reliable. In the case of the Buffalo River watershed, we are currently updating land use through the analysis of 2000 digital orthoquads.

Soils data provided with BASINS were compiled by generalizing detailed soil maps. The soil coverage contains attribute fields such as soil type, permeability, infiltration, erodibility, $\mathrm{pH}$, plasticity, and percent clay, silt, and/or sand for each soil polygon. The Watershed Report option in BASINS can provide an average value of a particular attribute by sub-watershed and the value of that attribute by individual soil unit. Values are calculated through a combination of aggregation methods such as area-weighting and depth integration. This information can be useful in attaining some of the parameter values for the model.

A digital elevation model (DEM) of the study area is shown in Figure 20.2. The resolution of the elevation data is $984 \times 984$ feet $(300 \times$ 
$300 \mathrm{~m}$ ) grid cells. Elevation in the watershed ranges from 571-1,932 feet (174$589 \mathrm{~m}$ ). The elevation data can be used to calculate the slope of the overland flow plane, which is one of the parameters in the model.

In this study the general stream network information (RF1) was used. RF1 is a vector database that was prepared by the U.S. EPA in 1982 from National Oceanographic and Aeronautical Administration (NOAA) aeronautical charts at a scale of 1:500,000 (http://www.epa.gov/OST/BASINS/metadata/rfl.htm). The data were prepared in ArcView format for specific use with BASINS Version 2.0.

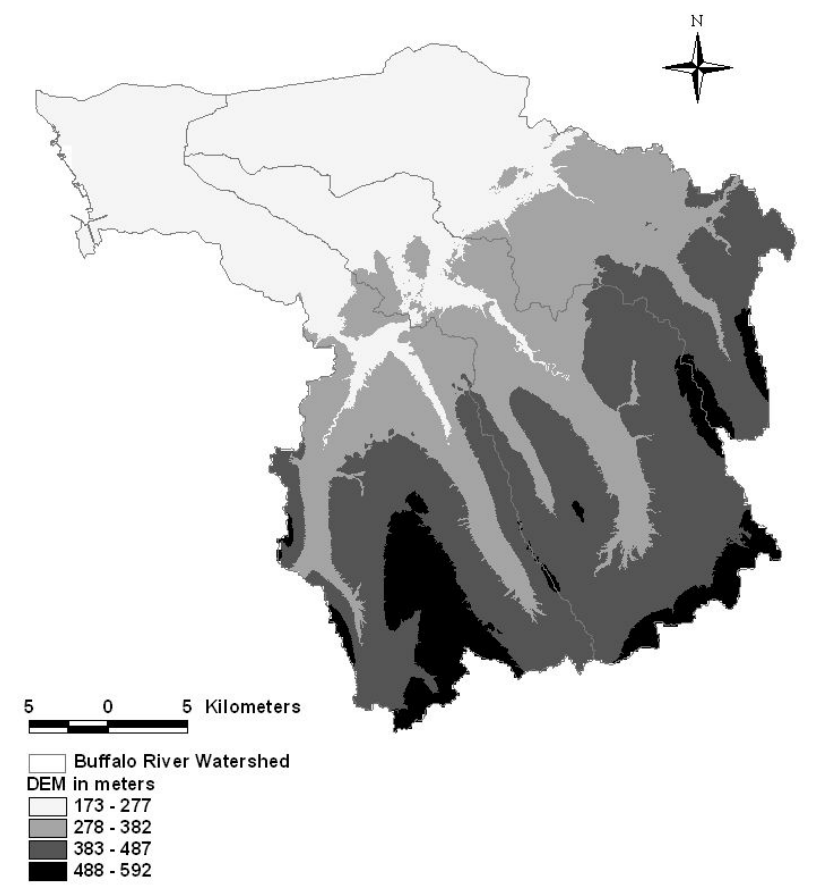

Figure 20.2 DEM of the Buffalo River watershed.

Each reach has a unique identifier for which stream characteristics such as length, slope, and mean width, depth, temperature, and $\mathrm{pH}$ are attached. Data from the RF1 coverage are used to generate the cross-sectional profiles of modeled reaches and construct the rating curves for flow calculations. The rating curves can be adjusted to actual stream morphology by modifying the cross-section characteristics. Frothingham and Perrelli (2001) compared the 
cross-sectional profiles provided in the RF1 database with surveyed profiles from several locations along Cazenovia Creek. Although they found differences between the RF1 profiles and surveyed profiles, flow estimates did not change significantly when the surveyed profiles were used in the model.

\subsubsection{Hydrometeorologic and Sediment Data}

For all initial discharge calibration and validation runs, the rainfall data used to drive the HSP-F model were daily rates from the Buffalo Airport.

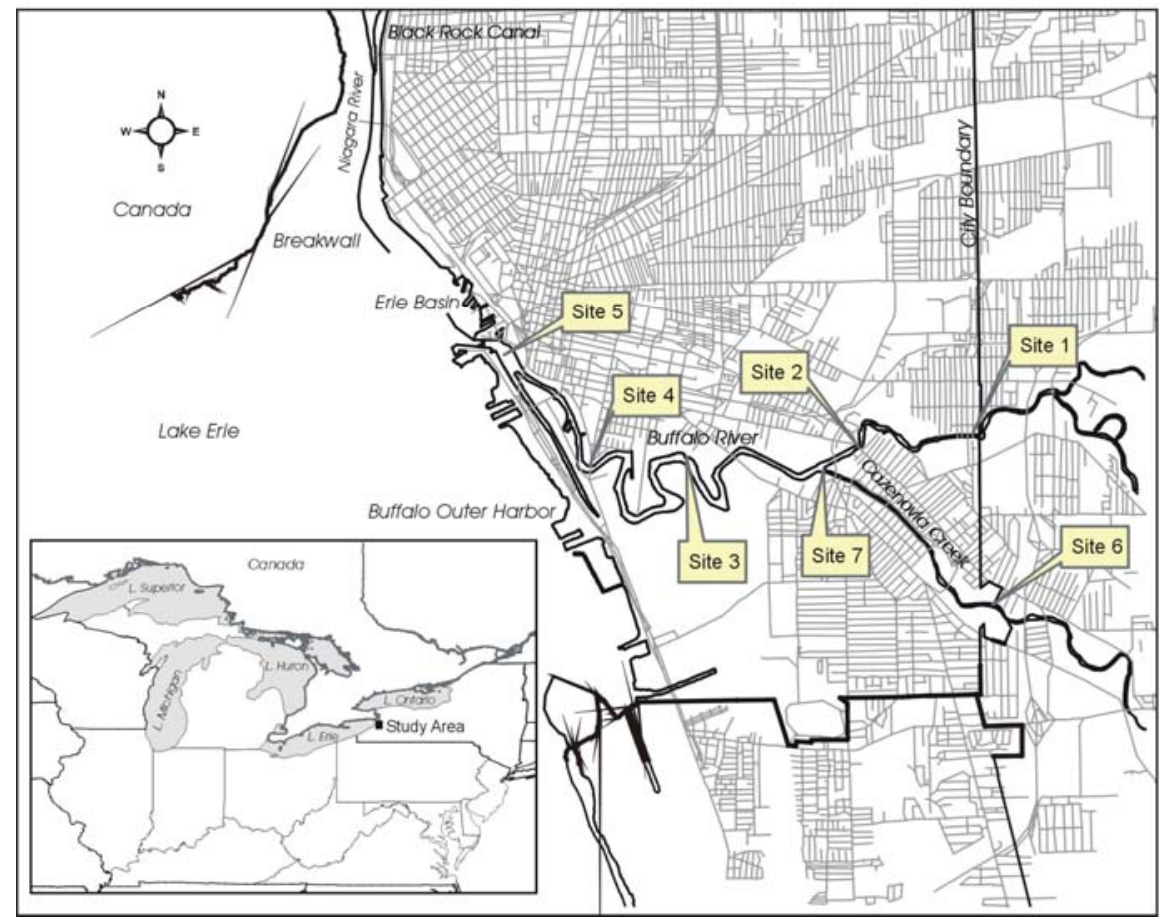

Figure 20.3 Lower Buffalo River showing location of water quality sampling and Hydrolab sites used in the Long Term Control Plan study.

Flow data for the calibration and validation runs were daily mean discharge values determined at the USGS gauge stations on the three major tributaries to the Buffalo River: Cayuga Creek, Buffalo Creek, and Cazenovia Creek 
(Figure 20.1). Suspended sediment concentration data were collected at seven sites (Figure 20.3) through two storm events and two dry weather periods as part of the LTCP effort. The storm samples were collected from a $1 \mathrm{~m}$ depth, mid-channel, at intervals of 1, 2, 3, 4, 6, 12, 18, 24, 36, and 48 hours after the initiation of CSO discharge. Hydrolab Datasonde 4a's also were installed at each site and recorded temperature, $\mathrm{pH}$, conductivity, dissolved oxygen, and turbidity at 15 min intervals between April 17, 2000 and November 18, 2000, a total of 30 weeks. Details on installation, maintenance, and data analysis for the Hydrolabs is provided by Irvine et al. (in press).

\subsection{Model Calibration and Validation for River Discharge}

The NPSM (Nonpoint Source Model)/HSP-F model in the BASINS system, version 2 was used for this project. Subsequent to the project completion, BASINS version 3 was released and HSP-F within the newer version is referred to as winHSP-F.

A literature review was conducted to help identify appropriate parameters for a sensitivity analysis (Laroche et al., 1996; Fontaine and Jacamino, 1997; Jacamino and Fields, 1997; Guther et al., 1997; Srinivasan et al., 1998; Carrubba, 2000; Lee, 2000) and using a continuous modeling approach and daily mean flow for the period May 1 through October 31, 1990, it was determined that the parameters USZN (upper zone nominal soil moisture storage) and LZSN (lower zone nominal soil moisture storage) had the greatest influence on daily mean flow, particularly in relation to storm event peak and volume. The parameters AGWRC (basic groundwater recession rate) and INFILT (index to infiltration capacity) tended to have the greatest impact on baseflow characteristics. Sensitivity analysis is not a principal focus of this chapter, but is detailed elsewhere (Perrelli and Irvine, 2001).

In this project, the model was calibrated for the three sub-watersheds: Cayuga Creek, Buffalo Creek, and Cazenovia Creek. It is recommended that calibration be based upon several years of simulation in order to evaluate parameters under different climatic, soil, and water quality conditions (Bicknell et al., 1996). Three years were selected for model calibration; May 1- October 31 1990, 1992, and 1995. These years were chosen because they represented average hydrologic conditions (1990), wet hydrologic conditions (1992) and dry hydrologic conditions (1995) (Lee, 2000). USGS gauge stations on Cazenovia Creek (04215500), Buffalo Creek (04214980), 
and Cayuga Creek (04215000) were used for model comparison. Observed flow data from each of these gauge stations were downloaded from the USGS web site for the specified time periods.

Default parameter values are provided for the model, but not surprisingly, these values required calibration for the modeled flow values to approximate observed flow conditions. For example, Figure 20.4 represents modeled and observed flow conditions for Buffalo Creek in 1992 based on default values for pervious land, impervious land, and reaches parameters in NPSM/HSP-F. The modeled values were representative of baseflow conditions, but underestimated high flow conditions. Default simulation would not provide an acceptable management tool for the Buffalo River watershed.

The NPSM/HSP-F model subsequently was calibrated for each subwatershed, by land use. HSPFParm (an interactive database of calibrated NPSM/HSP-F values for 60 watersheds across the U.S.) was used to help guide the selection of a range of parameter values (see Donigian et al., 1999). The calibration procedure ultimately considered 21 parameters for each of four land use types within the three sub-watersheds.

Example calibration results for each of the three sub-watersheds are shown in Figure 20.5 and qualitatively indicate that the model is capable of estimating flow rates for the watershed. The range of calibrated parameter values is shown in Table 20.1. Various measures are reported in the literature to quantitatively assess goodness-of-fit, but linear regression and the Nash Sutcliffe coefficient of efficiency are amongst the most common. Values for the Nash Sutcliffe (NS) coefficient can range between $-\infty$ (poor) to 1 (perfect).

This coefficient is useful in identifying systematic bias in the model (i.e. over- or under-estimation) even when the $r^{2}$ from linear regression is high (Carrubba, 2000). It also has been suggested (Carrubba, 2000) that because flow generally is not normally-distributed, regression between the observed and modeled values should be based on the log-transformed data. Goodnessof-fit measures $\left(\mathrm{r}^{2}\right.$ on log-transformed flow data and Nash Sutcliffe coefficient) for the calibration runs of daily mean flow from the three creeks in 1990, 1992, and 1995 are shown in Table 20.2. For comparison purposes, goodness-of-fit results reported in other studies are shown in Table 20.3.

After flows were calibrated for each of the three sub-watersheds, a validation run from May 1- October 31 was conducted using observed flow data from 1989. This year was chosen because it was a year of near typical rainfall and flow data were available for all three creeks in the watershed for this time period. The validation runs for the three sub-watersheds are shown in Figure 20.6. 
Table 20.1 Range of calibration parameters for the years 1990, '92, '95.

\begin{tabular}{|c|c|c|c|c|}
\hline Parameter & Parameter Description & $\begin{array}{l}\text { Range, } \\
\text { Cazenovia }\end{array}$ & $\begin{array}{l}\text { Range, } \\
\text { Cayuga }\end{array}$ & $\begin{array}{l}\text { Range, } \\
\text { Buffalo }\end{array}$ \\
\hline \multicolumn{5}{|c|}{ PWAT-PARM2 } \\
\hline LZSN & Lower Zone Nominal Storage, in. & $4.0-6.5$ & $6.0-9.0$ & $5.0-7.0$ \\
\hline INFILT & $\begin{array}{l}\text { Index to the Infiltration Capacity } \\
\text { of the Soil, in./hr }\end{array}$ & $0.04-0.1$ & $\begin{array}{c}0.0012- \\
0.012\end{array}$ & $0.02-0.04$ \\
\hline LSUR & $\begin{array}{l}\text { Length of Assumed Overland } \\
\text { Flow Plane, ft. }\end{array}$ & 250 & 400 & 300 \\
\hline SLSUR & Slope & 0.043 & 0.035 & 0.02 \\
\hline KVARY & $\begin{array}{l}\text { Groundwater Recession Flow } \\
\text { Parameter, 1/in. }\end{array}$ & $0-0.5$ & $0-0.3$ & $0-2.0$ \\
\hline AGWRC & $\begin{array}{l}\text { Groundwater Recession Rate if } \\
\text { KVARY is } 0 \text { and there is No } \\
\text { Inflow to Groundwater, } 1 \text { /day }\end{array}$ & $0.92-0.99$ & $0.90-0.95$ & $0.95-0.98$ \\
\hline \multicolumn{5}{|c|}{ PWAT-PARM3 } \\
\hline DEEPFR & $\begin{array}{l}\text { Fraction of Groundwater Inflow } \\
\text { which will Enter Deep } \\
\text { Groundwater and be Lost }\end{array}$ & $0.1-0.2$ & $0.1-0.5$ & 0.1 \\
\hline BASETP & $\begin{array}{l}\text { Fraction of PET which can be } \\
\text { Satisfied from Baseflow }\end{array}$ & $0.02-0.03$ & 0.02 & 0.02 \\
\hline \multicolumn{5}{|c|}{ PWAT-PARM4 } \\
\hline USZN & Upper Zone Nominal Storage, in. & $0.24-0.36$ & $2.0-3.25$ & $0.56-0.84$ \\
\hline NSUR & $\begin{array}{l}\text { Manning's n for Overland Flow } \\
\text { Plane }\end{array}$ & 0.2 & 0.2 & 0.2 \\
\hline INTFW & Interflow Inflow Parameter & $1.25-1.5$ & $0.7-0.95$ & $1.0-1.25$ \\
\hline IRC & $\begin{array}{l}\text { Interflow Recession Parameter, } \\
1 / \text { day }\end{array}$ & $0.3-0.45$ & $0.4-0.6$ & $0.5-0.73$ \\
\hline LZETP & $\begin{array}{l}\text { Lower Zone PET Parameter; } \\
\text { Index to Density of Deep-rooted } \\
\text { Vegetation }\end{array}$ & $0.1-0.3$ & $0.1-0.4$ & 0.1 \\
\hline \multicolumn{5}{|c|}{ PWATER- STATE1 } \\
\hline CEPS & Interception Storage, in. & $0-0.1$ & $0.01-0.1$ & $0-0.01$ \\
\hline SURS & $\begin{array}{l}\text { Surface (Overland) Flow Storage, } \\
\text { in. }\end{array}$ & 0 & $0.001-0.01$ & $0-0.01$ \\
\hline UZS & Flag for Upper Zone Storage, in. & $0.5-2.5$ & $2.75-8.0$ & $1.25-3.25$ \\
\hline IFWS & Interflow Storage, in. & $0.07-0.1$ & $0.01-0.1$ & $0-0.07$ \\
\hline LSZ & Lower Zone Storage, in. & $8.0-10.0$ & $3.0-9.0$ & $4.0-10.0$ \\
\hline AGWS & Active Groundwater Storage, in. & $0-0.1$ & $0.01-0.25$ & $0.01-0.25$ \\
\hline GWVS & $\begin{array}{l}\text { Index to Groundwater Slope; } \\
\text { Measure of Antecedent Active } \\
\text { Groundwater Inflow, in. }\end{array}$ & $0-0.01$ & 0.01 & 0.01 \\
\hline
\end{tabular}




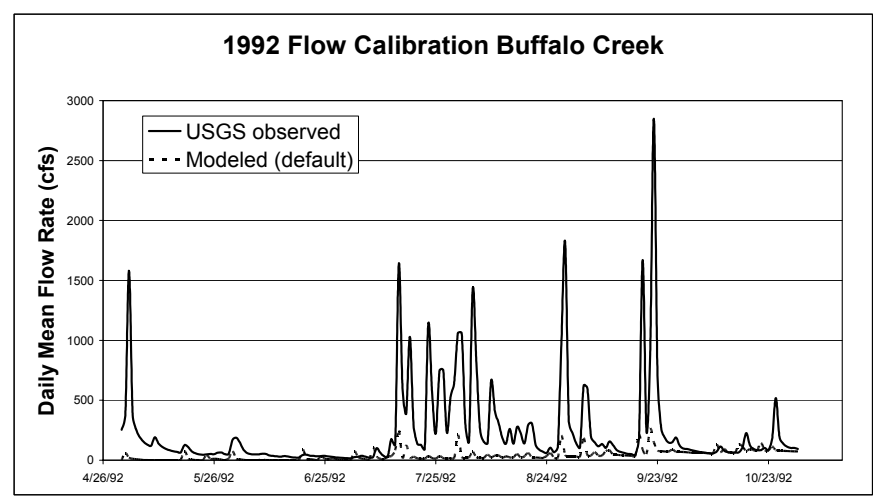

Figure 20.4 Model run using default values for the calibration parameters.

Table 20.2 Goodness-of-fit summary for calibration runs.

\begin{tabular}{ccccccc}
\hline & \multicolumn{2}{c}{ Cazenovia Creek } & \multicolumn{2}{c}{ Cayuga Creek } & \multicolumn{2}{c}{ Buffalo Creek } \\
& $\mathrm{r}^{2}$ & $\mathrm{NS}$ & $\mathrm{r}^{2}$ & $\mathrm{NS}$ & $\mathrm{r}^{2}$ & $\mathrm{NS}$ \\
\hline 1990 & 60 & 0.33 & 73 & 0.50 & 56 & 0.06 \\
1992 & 51 & 0.45 & 45 & -0.04 & 44 & 0.03 \\
1995 & 42 & 0.35 & 47 & 0.41 & 37 & 0.47 \\
\hline
\end{tabular}

Table 20.3 Goodness-of-fit summaries as reported in the literature.

\begin{tabular}{lcccc}
\hline Reference & $\begin{array}{c}\text { Range of } \mathrm{r}^{2} \\
\text { (calibration } \\
\text { runs) }\end{array}$ & $\begin{array}{c}\text { Range of } \mathrm{r}^{2} \\
\text { (validation } \\
\text { runs) }\end{array}$ & $\begin{array}{c}\text { Range of NS } \\
\text { (calibration } \\
\text { runs) }\end{array}$ & $\begin{array}{c}\text { Range of NS } \\
\text { (validation } \\
\text { runs) }\end{array}$ \\
\hline Carrubba, 2000 & $44-75$ & $64-71$ & $-0.66-0.45$ & $0.31-0.37$ \\
Laroche et al., 1996 & 53 & 45 & 0.51 & 0.12 \\
Srinivasan et al., & -- & -- & $0.15-0.71$ & 0.57 \\
1998 & -- & 69 & -- & -- \\
Brun and Band, 1999 & $67-77$ & $50-76$ & -- & -- \\
Love and Donigian & 6 & & & \\
\hline
\end{tabular}

Table 20.4 Goodness-of-Fit summary, validation run.

\begin{tabular}{ccccccc}
\hline & \multicolumn{2}{c}{ Cazenovia Creek } & \multicolumn{2}{c}{ Cayuga Creek } & \multicolumn{2}{c}{ Buffalo Creek } \\
\hline & $\mathrm{r}^{2}$ & $\mathrm{NS}$ & $\mathrm{r}^{2}$ & $\mathrm{NS}$ & $\mathrm{r}^{2}$ & NS \\
\hline 1989 & 49 & -1.1 & 51 & -1.1 & 53 & -1.1 \\
\hline
\end{tabular}


Goodness-of-fit measures $\left(\mathrm{r}^{2}\right.$ on log-transformed flow data and Nash Sutcliffe coefficient) for the validation run are shown in Table 20.4. For comparison purposes, goodness-of-fit measures reported for validation runs from other studies are summarized in Table 20.3.

Based on qualitative evidence, as shown in Figures 20.5 and 20.6, as well as statistical analysis $\left(r^{2}\right.$ between observed and modeled flows; Nash Sutcliffe coefficient), and a review of the literature, (Table 20.3) it can be concluded that calibration and validation results were acceptable. Certainly, the results were comparable to those reported in the literature for a variety of watersheds (e.g. Laroche et al., 1996; Srinivasan et al., 1998; Brun and Band, 1999; Carrubba, 2000; Love and Donigian, 2002). However, larger model errors frequently were traced back to the rainfall data that were used to drive the runoff simulations. The rainfall record used in the calibration and validation runs was for only one gauge site, the Buffalo Airport. Other studies have found that differences between simulated and observed storm flows may result from the inability of a single rain gauge to reflect storm patterns of a particular area (Brun and Band, 1999; Carrubba 2000; Engelmann et al., 2002). The way in which spatial variability of rainfall affects model performance for the Buffalo River watershed is discussed in the next section.

\subsubsection{Spatial Variability of Rainfall and Discharge Estimates}

Observation of weather radar and qualitative notation of the field crews during the summer of 2000 indicated that considerable spatial variability occurred in rainfall patterns. As part of the LTCP field effort, a total of 13 rain gauges were operated throughout the city in 2000 and data for these gauges were obtained from the Buffalo Sewer Authority.

Channel 4 (WIVB) in Buffalo also maintains a rain gauge network and data were obtained from an additional eight gauge sites for 2000. Finally, rainfall data for two National Weather Service gauges (Colden and Wales) that we became aware of after the initial NPSM/HSP-F calibrations (discussed above) also were obtained.

Rainfall events for the months of May and June, 2000 were examined in an effort to identify the extent of spatial variability within the watershed. In particular, we focused on four events (May 18, June 9, June 11, and June 24) for which rainfall exceeded 1 inch $(25.4 \mathrm{~mm})$ at a subset of the gauges. These events also were selected because they exhibited the greatest number of gauges that were operational during the event. 

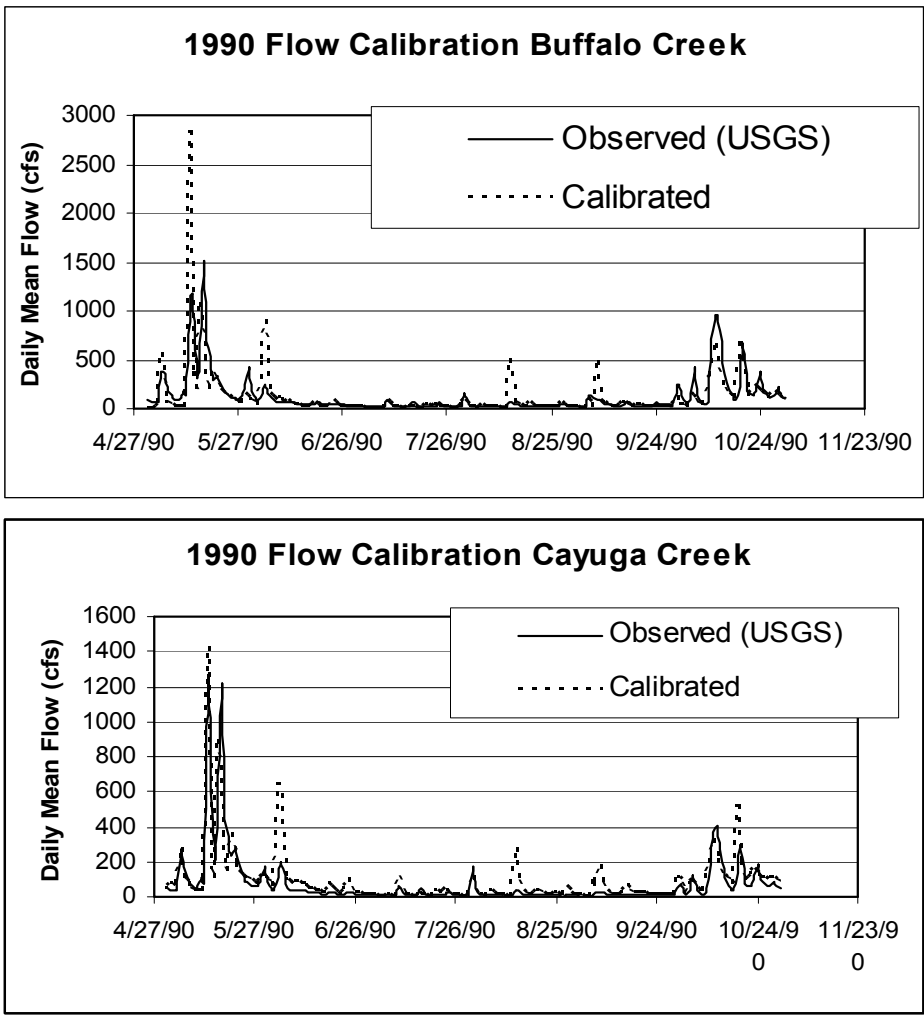

1990 Flow Calibration Cazenovia Creek

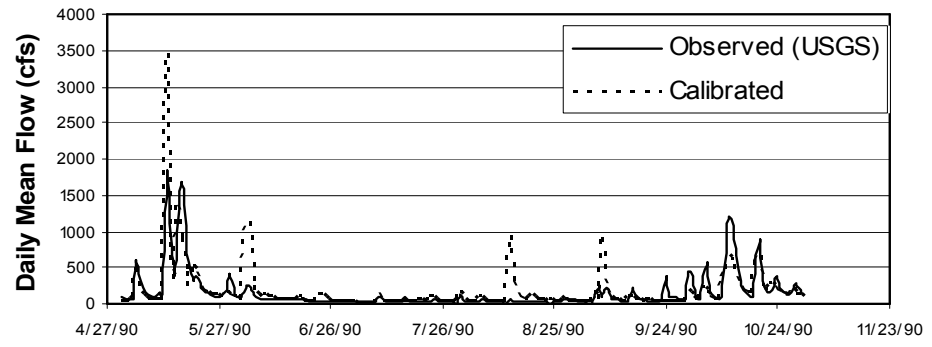

Figure 20.5 Calibration for the average hydrologic year, 1990. 

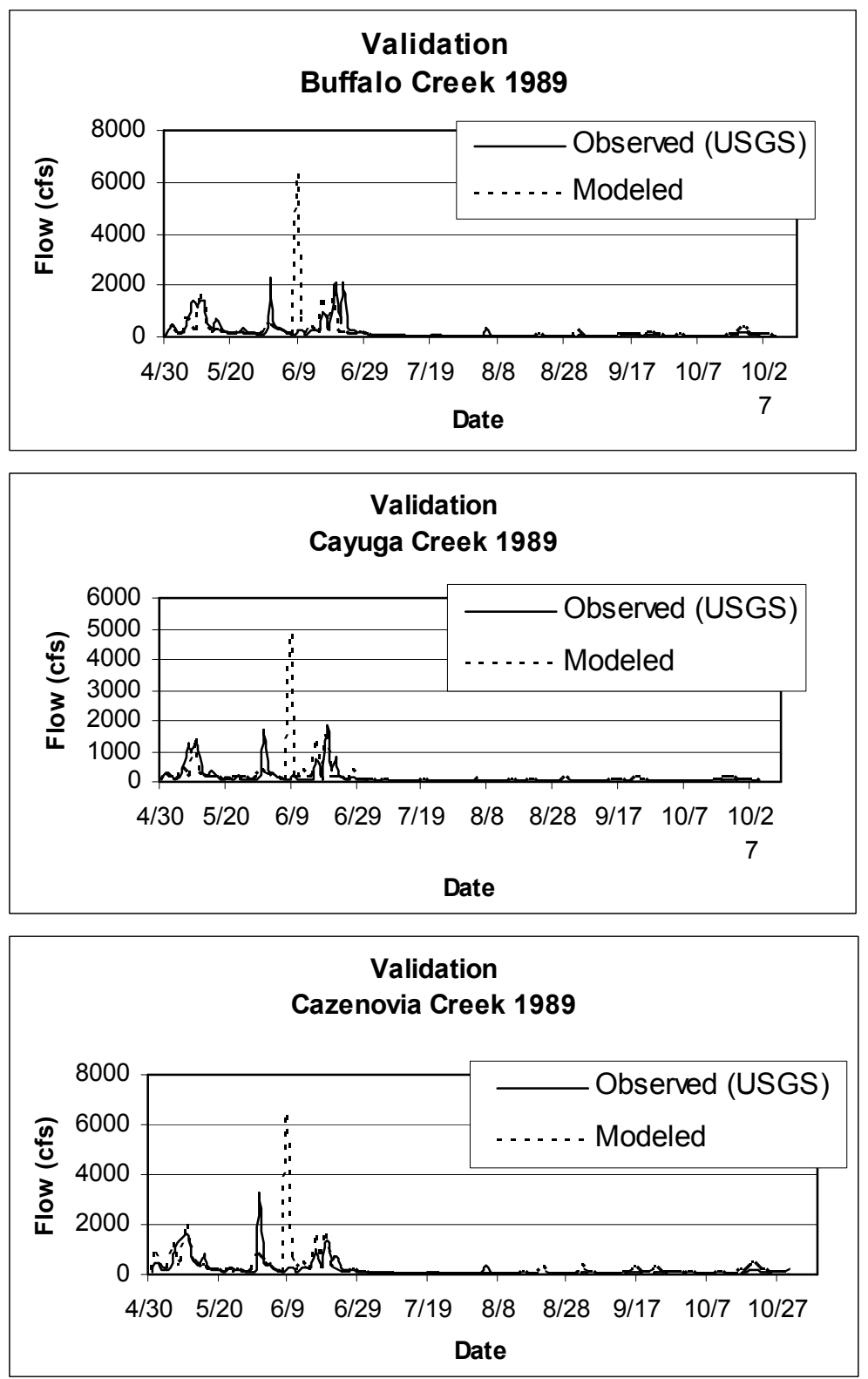

Figure 20.6 Model validation results, 1989. 


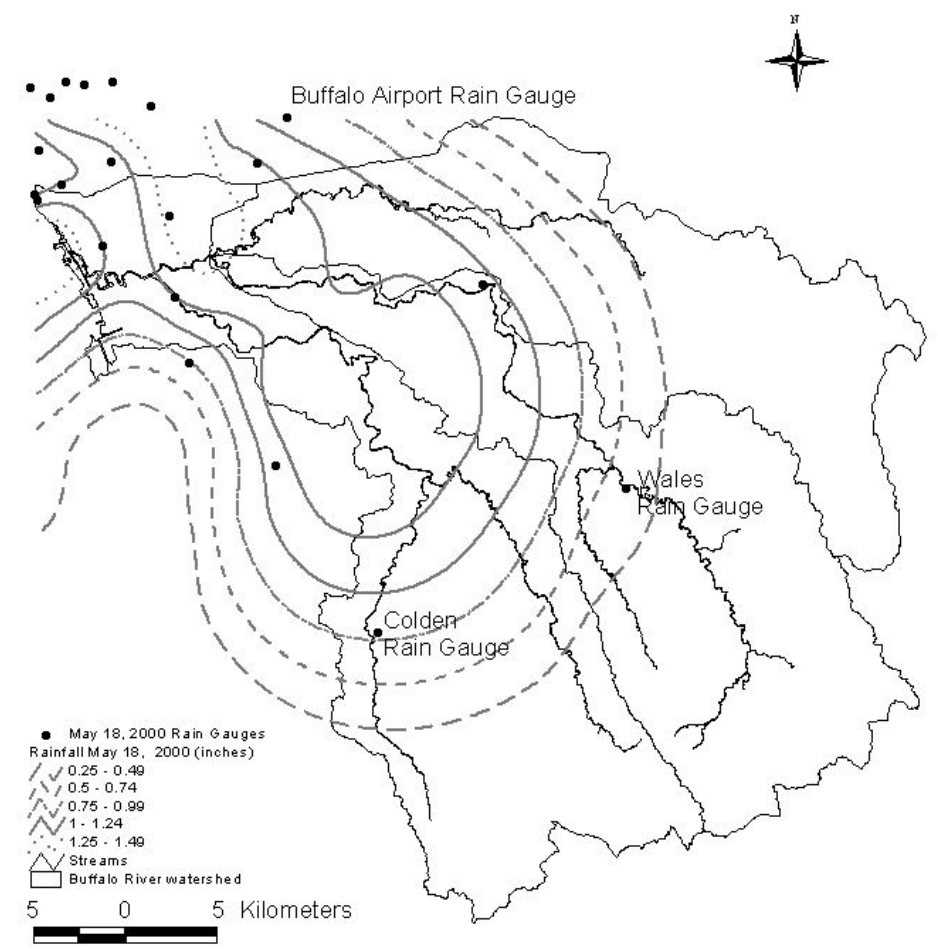

Figure 20.7a Spatial variability of rainfall. Analysis done using ArcView's Spatial Analyst, rainfall event of May 18, 2000.

The rainfall data were visualized using the Spatial Analyst package of ArcView 3.2 (e.g. Figures $20.7 \mathrm{a}, \mathrm{b}$ ) and as can be seen, rainfall from the Buffalo Airport may not always represent conditions for the entire watershed. For example, observed peak daily mean flow associated with the June 9, 2000 storm occurred on June 10 at all gauge stations. The daily mean flow, adjusted for basin area, was $2.24 \mathrm{cfs} / \mathrm{square}$ mile for Cayuga Creek, $2.32 \mathrm{cfs} / \mathrm{square}$ mile for Buffalo Creek, and $1.17 \mathrm{cfs} / \mathrm{square}$ mile for Cazenovia Creek.

The spatial pattern of rainfall (Figure 20.7b) indicated that the greatest rainfall was received in the Cayuga and Buffalo Creek sub-watersheds, while considerably less was received in the Cazenovia Creek sub-watershed. Use of rainfall data from the Buffalo Airport as input to the model for this storm clearly would result in a simulation that over-estimated observed runoff. 
Because of the spatial variability in the rainfall it was decided to investigate the possibility of developing a more spatially-representative rainfall data set for input to the model. This spatially-representative rainfall record was used for model validation for the period May 1-October 31, 2000.

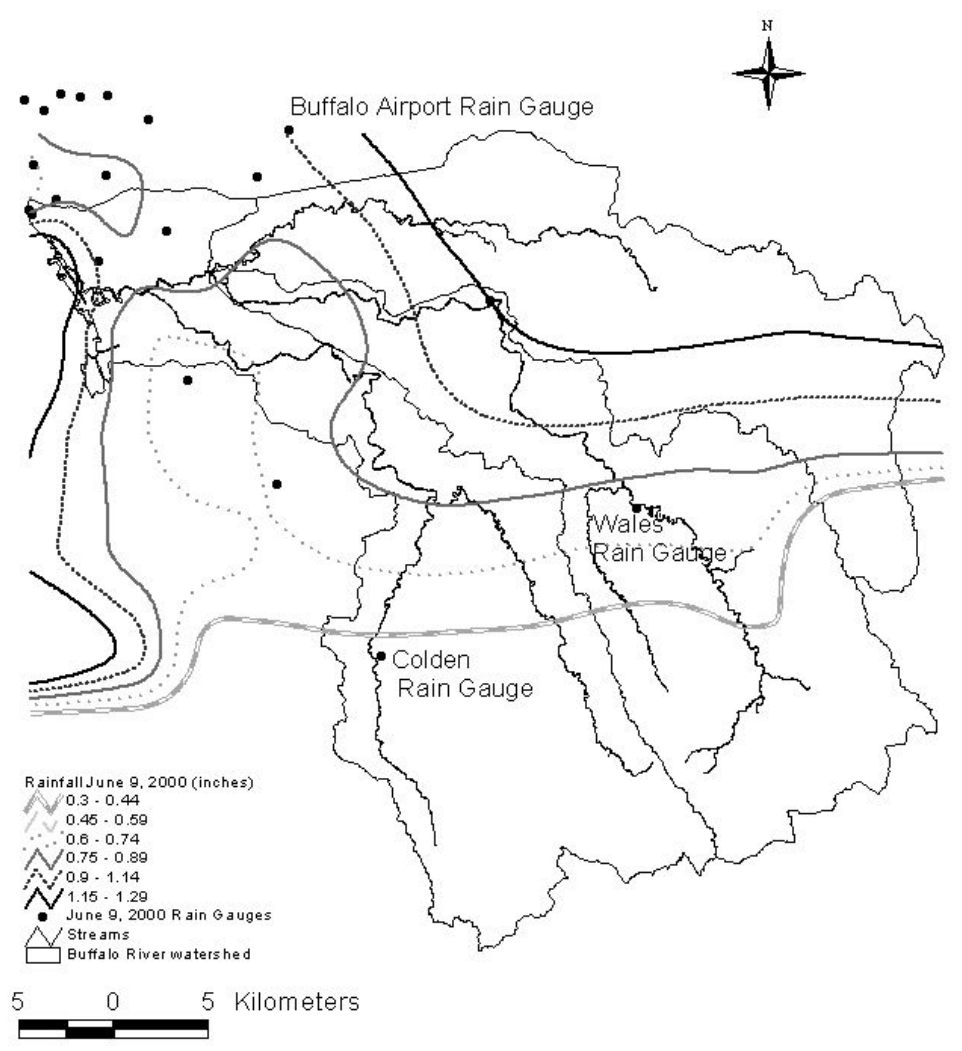

Figure 20.7b Spatial variability of rainfall. Analysis done using ArcView's Spatial Analyst, rainfall event of June 9, 2000.

The rain gauges maintained by the Buffalo Sewer Authority (within the city of Buffalo) and Channel 4 (throughout the watershed) do not have sufficiently long records to be useful for the analytical approach employed in the LTCP study. Therefore, it was necessary to focus rain data analysis on three National Weather Service gauge sites, the Buffalo Airport, Colden, and Wales (Figure 20.7). A complete record of hourly rainfall was available for the Buffalo Airport, but unfortunately the hourly rainfall records for Colden and 
Wales were not complete. To fill in missing data, a regression analysis was done for the daily total rainfall between all three sites (e.g. Patra, 2001). The daily total precipitation predicted from the regression was then distributed on an hourly basis (as required for input to the model) using the hourly rainfall distribution observed at the nearest of the other two gauges (also see Engelmann et al., 2002). An arithmetic mean was then calculated using the data from each of the three gauges to determine the spatially-representative rainfall record.

Initially, the validation run was done using the spatially-representative rainfall record. Three additional validation runs were done using just the rainfall data from the Buffalo Airport, the rainfall data from the Colden gauge, and the rainfall data from the Wales gauge. Goodness-of-fit measures for the validation runs using the different rain datasets are summarized in Table 20.5.

Results of the validation run for the year 2000 using the spatiallyrepresentative (i.e. "average") rainfall data are good and certainly are comparable to results reported in the literature (e.g. Laroche et al., 1996; Srinivasan et al., 1998; Brun and Band, 1999; Carrubba, 2000; Love and Donigian, 2002). The results presented in Table 20.5 also show that the use of spatially-representative rainfall data can improve model prediction, both in terms of increasing the percent variation explained in the data $\left(r^{2}\right)$ and reducing systematic bias in the model estimates (i.e. higher NS value), as compared to the use of the Buffalo Airport rainfall data, alone.

\subsection{Calibration of Sediment Erosion, Transport, and Deposition}

Consideration of sediment erosion, transportation, and deposition within the Buffalo River watershed is important for two reasons. First, the lower Buffalo River is a federally-designated navigable channel that is maintained through dredging to ensure safe passage of lake-going ships. There is interest in controlling sediment inputs to the lower river through Best Management Practices, thereby reducing the costs of dredging. Second, many contaminants of concern for the Buffalo River AOC (bacteria, metals, and PAHs) can be preferentially transported in association with suspended sediment. Therefore, an understanding of sediment dynamics is important to fully assess the fate of associated contaminants. NPSM/HSP-F simulates the erosion, transport, and deposition of sediment from pervious and impervious surfaces and routes the 
eroded sediment through a defined river network. Simulation of erosion processes associated with pervious land is based on the ARM and NPS models first developed by Donigian and Crawford (1976a, b) and also is heavily influenced by the work done for the Universal Soil Loss Equation (USLE). Gully erosion is considered separately from overland sheet erosion. Simulation of impervious land sediment processes is done following the methods described by Donigian and Crawford (1976b).

Once the sediment is eroded and removed from the pervious and impervious surfaces, it is routed along the defined channel network. For the channel routing, NPSM/HSP-F divides the inorganic sediment load into three components (sand, silt, and clay), each with its own properties. Parametric information required for cohesive sediment (silt and clay) includes:

- $\quad$ particle diameter $(D)$,

- particle settling velocity in still water $(W)$,

- particle density (RHO),

- critical shear stress for deposition (TAUCD),

- critical shear stress for scour (TAUCS), and

- erodibility coefficient (M).

The transport of sand sized material was calculated as a power function of velocity and as such required information on average stream velocity and the volume of water within the channel.

A lengthy time series of observed suspended solids data was not available for model calibration. However, as noted in Section 20.3.2, turbidity was continuously measured at various sites along the Buffalo River in 2000 and relationships between suspended solids and turbidity were developed using least squares regression. The development of these relationships is discussed in detail by Irvine et al. (2002), but briefly, the slopes of the regressions were significantly different from $0(\alpha=0.05)$ and the $r^{2}$ values ranged between 0.67 and 0.74 . For the purpose of model calibration we ran the daily mean turbidity values through the appropriate regression equation to construct a suspended solids time series. This constructed suspended solids time series hereafter is referred to as the "observed" suspended solids concentration. It is recognized that this approach introduces errors associated with the regression analysis, although the correlation between the two variables was strong. Due to the lack of sample data, this was the best approach available to help ensure that the model was providing a reasonable simulation throughout the year. Initial estimates of parameter values were obtained from various sources, including Donigian et al., (1999); Raggio et al., (1988); U.S. Army Corps of Engineers 
(1988); and image and settling velocity analysis of suspended sediment grab samples (following the methodology outlined by Irvine and Droppo, 1999).

Results of the calibration run for an example river reach that represents Cazenovia Creek, near the mouth, and for the lower Buffalo River, near the Ohio St. bridge, are shown in Figure 20.8. Visually, the observed and modeled sediment time series for the two reaches corresponded, although quantitatively, the $r^{2}$ was low (in the range of 0.29 ). The model did a better job of representing erosion and transportation from the upper part of the watershed, as evidenced by the results for Cazenovia Creek. It seems that the model had greater difficulty in representing the sediment deposition processes within the more hydraulically complex dredged channel. Furthermore, because the Buffalo River sediment is flocculated, measured settling velocities were different than those assumed under Stokes Law (e.g. Irvine et al., 1999), and particle density (RHO) can approach 1.0. The model specifies a minimum density of 2.0. Error in comparison between observed and modeled suspended sediment concentration also will result from the use of a rating curve with turbidity to determine "observed" concentration. Our calibrated pervious land erosion parameters were similar to those reported in the literature and summarized by Engelmann et al. (2002). Our correlation and Nash-Sutcliffe results also were remarkably similar to those reported by Engelmann et. al. (2002).

\subsection{Discussion and Conclusion}

Overall, BASINS potentially is a valuable tool. It certainly was effective in helping to develop watershed contaminant loading estimates that could be compared to CSO loading estimates as part of the City of Buffalo LTCP. In this case, it was shown that loadings from the upper watershed were greater than from the CSOs and this information was used in making decisions regarding CSO abatement options. More recently, Irvine et al. (2003a) used BASINS version 3 to delineate 101 sub-watersheds (rather than 3 ) within the Buffalo River watershed to assess potential septic system inputs on a subwatershed scale. The model also was useful for this application. However, for many applications the HSP-F model within BASINS may suffer from overparameterization, a common criticism for physically-based models (e.g. Beven, 1989). The BASINS tool will be most effectively used by persons with extensive knowledge of GIS and watershed hydrology. For example, as part of the septic system project, Irvine et al. (2003a) provided training in the 
application of BASINS for personnel from the Erie County Department of Environment and Planning. One of the mandates of the Erie County Department of Environment and Planning is to take the lead in developing watershed management plans. The County personnel concluded that most local governments who might be interested in this type of management tool lack the funds or the experienced personnel to devote to model development.
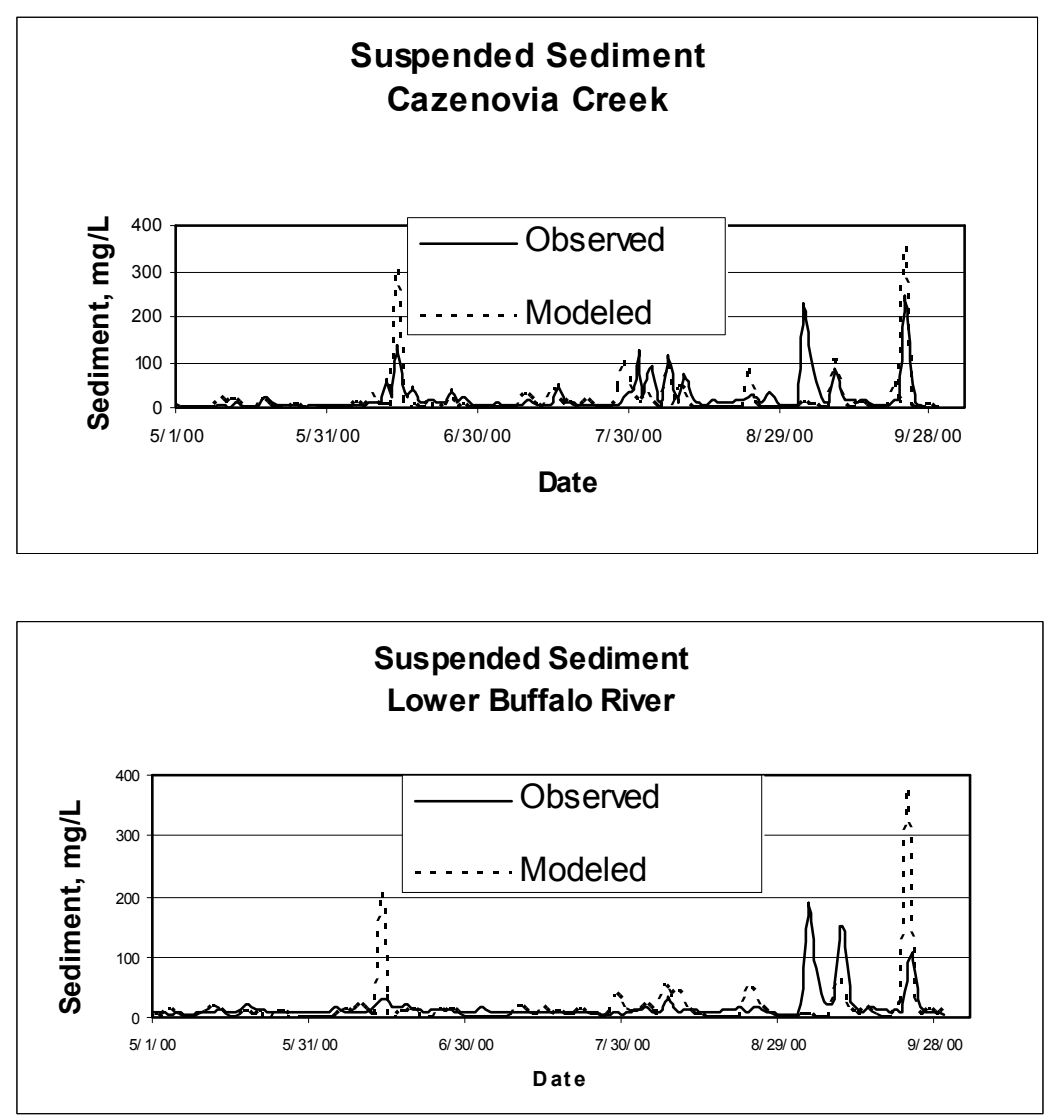

Figure 20.8 Model calibration results for suspended sediment estimates in Cazenovia Creek, near the mouth (Hydrolab site 7) and for the lower Buffalo River (Hydrolab site 4). 
The importance of good rainfall data should not be overlooked and this point has been emphasized at this conference over the years (e.g. Kouwen and Soulis, 1994; Nguyen and Wang, 1996; Rivard, 1996; Burian and Durrans, 2002; James et al., 2002). This issue is particularly important in areas like Buffalo, which due to its location at the eastern end of Lake Erie, experiences considerable spatial variation in rainfall patterns. An approach such as spatial averaging of rainfall data appeared to improve runoff predictions.

BASINS users should be aware that the land use coverages provided as part of the system are old (mid-1970s to early 1980s) and may not accurately reflect current land use. It is for this reason that we are updating the Buffalo River watershed coverages. Although the river cross sections provided by the BASINS system differed from surveyed cross sections, Frothingham and Perrelli (2001) did not find model results particularly sensitive to those differences.

Model results for estimating sediment erosion and transport on a daily basis were not as accurate as the flow estimates, but this is typical because the errors in the hydrologic modeling are compounded by the complexities (and at times randomness) of the sediment processes. Although the model accommodates different particle sizes, it really cannot represent the flocculated nature of sediment, and in particular, the density of the flocculated sediment in the Buffalo River is much less than 2.0, the minimum value considered in the model.

\section{Acknowledgment}

This work was done in support of the Buffalo Sewer Authority's Long Term Control Plan. Thanks to Mr. Frank DiMascio, Buffalo Sewer Authority, Mr. Greg McCorkhill, Mr. Jim Caruso and staff at URS Corporation and to Mr. Jerel Bogdan, Mr. Ron Cavalieri, and Mr. Dante Zettler, Malcolm Pirnie, Inc., for their observations on the modeling approach and provision of rainfall data.

\section{References}

Anderson, J.R., Hardy, E.E., Roach, J.T., and Witmer, R.E.. 1976 A Land Use and Land Cover Classification System for use with Remote Sensor Data. Geological Survey Professional Paper 964. United States Government Printing Office, Washington. Beven, K. 1989. Changing Ideas in Hydrology- The Case of Physically-Based Models. Journal of Hydrology, 105: 157-172. 
Bicknell, B. R., Imhoff, J.C., Kittle, J.L. and Donigian, A.S. 1996. Hydrological Simulation Program- Fortran: User's Manual for release 11. US EPA.

Brun, S.E. and Band, L.E. 1999. Simulating runoff behaviour in an urbanizing watershed using Hydrologic Simulation Program - Fortran. http://www.unc.edu/depts/geog/them/models/hspf/hspfmodel.html.

Burian, S. and S. Durrans. 2002. "Short Time-Interval Rainfall Disaggregation for Continuous Hydrologic Simulation." Journal of Water Management Modeling R208-04. doi: 10.14796/JWMM.R208-04.

Carrubba, L. 2000. Hydrologic modeling at the watershed scale using NPSM. Journal of the American Water Resource Association, 36(6): 1237-1246.

Donigian, A.S., Jr. and Crawford, N.H. 1976a. Modeling Pesticides and Nutrients on Agricultural Lands, EPA 600/2-7-76-043.

Donigian, A.S., Jr. and Crawford, N.H. 1976b. Modeling Nonpoint Pollution from the Land Surface, EPA 600/3-76-083.

Donigian, A. S., Jr., Imhoff, J.C. and Kittle, J.L., Jr., 1999. HSPFParm: An Interactive Database of HSPF Model Parameters. Version 1.0, EPA-823-R-99-004.

Engelmann, C.J.K., Ward, A.D., Christy, A.D., and Bair, E.S. 2002. Application of the BASINS database and NPSM model on a small Ohio watershed. Journal of the American Water Resources Association, 38(1): 289-300.

Fontaine, T.A. and Jacomino, V.M.F. 1997. Sensitivity analysis of simulated contaminated sediment transport. Journal of the American Water Resources Association, 33(2): 313326.

Frothingham, K.M. and Perrelli, M.F. 2001. Assessing the representativeness of stream geomorphology parameters in BASINS. Middle States Geographer, 34: 48-54.

Guther, R.T., R.B. Scheckenberger and W.R. Blackport. 1997. "Use of Continuous Simulation for Evaluation of Stormwater Management Practices to Maintain Base Flow and Control Erosion." Journal of Water Management Modeling R195-04. doi: 10.14796/JWMM.R195-04.

Irvine, K. and I. Droppo. 1999. "Consideration of CSO Floc Characteristics for Modeling the Removal of Solids in a Detention Tank." Journal of Water Management Modeling R204-10. doi: 10.14796/JWMM.R204-10.

Irvine, K.N. and Eberhardt, A.J. 1992. Multiplicative, seasonal ARIMA models for Lake Erie and Lake Ontario water levels. Water Resources Bulletin, 28(2): 385-396.

Irvine, K.N., Stein, G.P. and Singer, J.K. 1992. An environmental guidebook to the Buffalo River. Proceedings, International Symposium on Environmental Dredging, September 30-October 2, 1992, Buffalo, NY, Erie County Environmental Education Institute, Inc., Ch. 2.

Irvine, K.N., Somogye, E.L., and Pettibone, G.W. 2002. Turbidity, suspended solids, and bacteria relationships in the Buffalo River watershed. Middle States Geographer, 35: 42-51.

Irvine, K.N., Perrelli, M., and Brown, N. 2003a. Septic System Pollution Prevention BMPs: Development of Public Outreach Approaches, Assessment, and Decisionmaking Tools for Local Government, Report to the New York State Water Resources Institute, $67 \mathrm{p}$.

Irvine, K.N, Perrelli, M.F., McCorkhill, G., and Caruso, J. 2003b. Sampling and modeling approaches to assess water quality impacts of combined sewer overflows - the 
importance of a watershed perspective. Proceedings of the 2nd Asian Pacific International Conference on Pollutants Analysis and Control, Vietnam National University, Ho Chi Minh City.

Irvine, K.N., Frothingham, K.M, Rossi, M.C., Pickard, S., Atkinson, J., and Bajak, T. 2003c. Contaminated sediment in the Buffalo River Area of Concern - Historical trends and current conditions. In. M. Munawar, ed. Sediment Quality Assessment and Management: Insight and Progress, Ecovision World Mongraph Series, Aquatic Ecosystem Health and Management Society, pp. 81-112.

Irvine, K.N., McCorkhill, G., and Caruso, J. in press. Continuous monitoring of conventional parameters to assess receiving water quality in support of CSO abatement plans. Water Environment Research.

Jacomino, V.M.F. and Fields, D.E. 1997. A critical approach to the calibration of a watershed model. Journal of the American Water Resources Association, 33(1): 143154.

James, W., P. Nimmrichter, R. James and R.B. Scheckenberger. 2002. "Robustness of the Rainpak Algorithm for Storm Direction and Speed." Journal of Water Management Modeling R208-06. doi: 10.14796/JWMM.R208-06.

Kouwen, N. and E. Soulis. 1994. "Weather Radar and Flood Forecasting." Journal of Water Management Modeling R176-16. doi: 10.14796/JWMM.R176-16.

Laroche, A-M., Gallichand, J., Lagacé, R. and Pesant, A. 1996. Simulating atrazine transport with HSPF in an agricultural watershed. Journal of Environmental Engineering, 122(7): 622-630.

Lee, T. 2000. Application of a GIS-based Watershed Model to Estimate Runoff and Bacteria Loads in Cazenovia Creek, New York. Unpublished Masters Thesis, State University of New York at Buffalo.

Love, J. and T. Donigian. 2002. "A Modeling System of Nutrient Loads to Long Island Sound from Connecticut Watersheds." Journal of Water Management Modeling R208-11. doi: 10.14796/JWMM.R208-11.

Meredith, D.D. and Rumer, R.R. 1987. Sediment Dynamics in the Buffalo River. Report, Department of Civil Engineering, State University of New York at Buffalo.

Nguyen, V. and H. Wang. 1996. "Regional Estimation of Short-Duration Rainfall Distribution using Available Daily Rainfall Data." Journal of Water Management Modeling R191-11. doi: 10.14796/JWMM.R191-11.

Patra, K.C. 2001. Hydrology and Water Resources Engineering, CRC Press, Boca Raton, $561 \mathrm{p}$.

Perrelli, M.F. and Irvine, K.N. 2001. Receiving Water Modeling - Buffalo River Interim Report on Hydrologic Calibration and Validation. Report to URS Corporation, 62p.

Raggio, G., Jirka, G., and Pacenka, S. 1988. Modeling and Field Studies of Sediment Transport in the Buffalo River, Erie County, NY. Report to the New York State Water Resources Institute, $77 \mathrm{p}$.

Rivard, G. 1996. "Design Storm Events for Urban Drainage Based on Historical Rainfall Data: a Conceptual Framework for a Logical Approach." Journal of Water Management Modeling R191-12. doi: 10.14796/JWMM.R191-12.

Sargent, D.H. 1975. Water Pollution Investigation: Buffalo River. U.S. EPA Report, EPA905/9-74-010. 
Sauer, D.E. 1979. An Environmental History of the Buffalo River. Buffalo Color Corporation, $88 \mathrm{p}$.

Srinivasan, M.S., Hamlett, J.M., Day, R.L., Sams, I., and Petersen, G.W. 1998. Hydrologic modeling of two glaciated watersheds in northeast Pennsylvania. Journal of the American Water Resources Association, 34(4): 963-978.

U.S. Army Corps of Engineers, 1988. Buffalo River Sedimentation Study.

U.S. Department of Agriculture, 1986. Soil Survey of Erie County, New York, U.S. Government Printing Office, 354-457:QL3, 384p., with maps.

U.S. EPA, 1999. Combined Sewer Overflows Guidance for Monitoring and Modeling. U.S. EPA Report, EPA 832-B-99-002.

U.S. EPA, 2001a. Protecting and Restoring America's Watersheds, U.S. EPA Report, EPA-840-R-00-001.

U.S. EPA, 2001b. Guidance: Coordinating CSO Long-Term Control Planning with Water Quality Standards Reviews, U.S. EPA Report, EPA-833-R-01-002.

U.S. EPA, 2001c. Total Maximum Daily Load (TMDL) Development for Fecal Coliform in the Crooked Creek Watershed (HUC 03160110) Cullman County, Alabama. U.S. EPA Region 4 Report.

Virginia Department of Environmental Quality, 2002a. Fecal Coliform TMDL for Blacks Run, Rockingham County, Virginia.

Virginia Department of Environmental Quality, 2002b. Fecal Colform TMDL for Christians Creek, Augusta County, Virginia.

Whittemore, R.C. and Beebe, J. 2000. EPA's BASINS model: Good science or serendipitous modeling? Journal of the American Water Resources Association, 36(3): 493-499. 